\title{
CLIMATIC REGIONS OF KOSOVO AND METOHIJA
}

\author{
Radomir Ivanović $^{\mathbf{1}}$, Aleksandar Valjarević ${ }^{1}$, Danijela Vukoičić ${ }^{\mathbf{1}}$, Dragan Radovanović ${ }^{1}$ \\ ${ }^{1}$ Faculty of Science and Mathematics, University of Priština, Kosovska Mitrovica, Serbia.
}

\begin{abstract}
The following the average and extreme values of climatic elements, specific climatic indices and field research, we can select three climatic types in Kosovo and Metohija - the altered Mediterranean, continental and mountainous type. The altered Mediterranean type is present in southern and western Metohija, to be specific, it affects the Prizren Field, the Suva Reka and Orahovac Valley as well as the right bank of the Beli Drim from Pećka Bistrica to the Serbia - Albania border. Gradually and practically unnoticeably, it transforms itself into a moderate continental type which dominates over the remaining valley and

mountainous parts of Kosovo. It affects parts of northern Metohija, Drenica and the entire Kosovo valley along with smaller sidelong dells - Malo Kosovo and Kosovsko Pomoravlje. Because of their exquisite heights, the mountains that complete the Kosovo Metohija Valley have a specific climatic type, at their lower slopes it is sub - mountainous and at the higher ones it is typically mountainous. Within these climatic types, several climatic sub regions are present. Their frontiers are not precise or sharp. Rather, their climatic changes are gradual and moderate from one sub-region to the other.
\end{abstract}

Key words: Climatic regions, climatic sub-regions, Kosovo and Metohija.

\section{INTRODUCTION}

The climatic regional division of Kosovo and Metohija has been made following the previous experiences of exploration with a great engagement in the very field. The quantity and the quality indicators of the regions and sub-regions have been determined according to the analysis of basic climatic elements (air temperature, precipitation, winds etc.) over many years. Apart from the average annual values, a special attention has been paid to annual flows, the position of extreme values, a number of typical days (summer, tropical, winter, icy), the lasting of a particular phenomenon (snow presence) as well as the other quantity indicators of a particular climatic region. Also, in order to show the climatic differences in Kosovo and Metohija in the best possible way, specific climate indicators have been in use- the rain factor (RF), the drought index (I), the thermo-drome quotient (q), (Vujević, 1956), as the assessment of dryness on an annual basis has been determined by Seljanin`s hydro thermic quotient (HTQ) adjusted to the conditions in Serbia (Otorepec, 1973). The data of standard meteorological stations that have been used are distributed in the territory of Kosovo and Metohija, one of which is the main one, eight of which are eight second class stations and 40 precipitation stations. The current distribution of stations is not good, but anyway it offers the possibilities of observing Kosovo and Metohija climate. Some stations have experienced the interruption of their work, so this is why the standard interpolation method has been used.

\section{GEOGRAPHICAL POSITION OF KOSOVO AND} METOHIJA

Starting with the basic principle of climatic regions, both regional and typological, also considering the known definition of climatic regions a climatic region is a particular place with specifically unique climate that is more or less different from the neighboring territories (Rakićević, 1980), we have come to the clear differentiation of similar yet different regions and sub-regions. The specific position of Kosovo and Metohija, its topographic diversity and other factors, have caused that even at a shorter mutual distance considerably different climatic types and sub-types have been formed. The very fact that over the Kosovo and Metohija territory there passes a frontier of the Mediterranean and continental pluvio metric regime (Vujević, 1955), is indicative of the climatic differences that are dominant in the area. 


\subsection{Region with altered Mediterranean climatic features}

In this climatic type, three similar yet different climatic sub-regions have been selected- the West Metohija sub-region, the Central Metohija sub-region and the Prizren sub-region.

$I_{a}$-West Metohija Climatic Sub-region. In geographic terms, this sub-region covers the territory of Dečani Podgora, Đakovica Has and the middle flow of the River Erenik and the Dečanska Bistrica. The sub-region has been selected because of the great amount of precipitation, the greatest one in the valley landscape of Kosovo (Junik 1424mm) and the specific pluviometric regime which is nearest the South Adriatic-Montenegrin type (the maximum value in November, December and January, with the minimum value in June, July and August). It is also recognizable for a huge amount of air humidity as the relative humidity on an annual basis is $76.7 \%$ as the annual value of the hydro thermic quotient is $1.39 \%$. The three summer months are dry with the HTQ from 0.7 to 0.9. The rain factor value is the greatest in the valley landscape of Kosovo and Metohija, higher than 90. Winters are not particularly cold; the presence of frosty days is 79.5 as of the icy ones is 14.1 . The average annual temperature is from 10 to $11^{\circ} \mathrm{C}$, the vegetation period (tav. $>5^{\circ} \mathrm{C}$ ) is 259 days long while the temperature sum is $3759^{\circ} \mathrm{C}$.

$I_{b}$-Central Metohija (Orahovac) climatic subregion. It covers the territory from the confluence of the rivers Klina and Pećka Bistrica to the north to the middle flow of the River Topluga to the south. It embraces the basin of the Beli Drim middle flow with its larger part on the left bank. To the east, it spreads itself to the slopes of the Drenica Mountains, the Crnovljeva and Nerodimska Mountains, while to the west it borders the West Metohija sub-region. It differs from the previous one in terms of a considerably smaller amount of precipitation and to a certain extent higher temperatures. The average annual air temperature is higher than $11^{\circ} \mathrm{C}$. The winters are not particularly cold while the summers are very warm, even hot, which is supported by the number of hot days (104) and very hot days (38). The entire length of vegetation period is 271 days with the temperature sum of approximately $4000^{\circ} \mathrm{C}$. This sub-region receives a considerably smaller amount of precipitation than the previously described sub-region - Orahovac 767mm, Suva Reka 688 mm. The maximum amount of precipitation is in November and the secondary maximum is in May. The smallest amount of precipitation is in August, with the secondary one in March. According to the values of the rain factor, these regions are classified as arid $(\mathrm{RF}<60)$ in accordance with the annual values the HTQ is insufficiently moist. A small number of snowy days (V. Krusa 14.8), a short presence of the snow cover (Orahovac 28.6) as well as a small number of stormy days, fewer than ten, is indicative of the moderate sub-regional climate which has been utilized through the cultivation of the famous Metohija vineyards that boast excellent grape quality.

Ic-Prizren Climatic Sub-region. It covers the area of the Prizren field and the lower flow of the River Beli Drim. The average annual temperature verges $12^{\circ} \mathrm{C}$. The average January temperature is positive $\left(0.16^{\circ} \mathrm{C}\right)$ while the average July temperature is higher than $22^{\circ} \mathrm{C}$. Therefore, the summers are hot and dry as the winters are mild and rainy. In this sub-region, there is the greatest number of summer days (96.8) and tropical days (33.3) as well as tropical nights (2.6) with the smallest number of frosty days in Kosovo (69.4). The vegetation period is 273 days long with the temperature sum of $4187^{\circ} \mathrm{C}$. In this sub-region, there are more than 2000 hours of sunshine. Prizren and the Beli Drim Valley approximately receive $750 \mathrm{~mm}$ of precipitation as its fringes receive slightly more. The maximum value of precipitation is in November and there is a less visible maximum in May. The minimum value of precipitation is in August and the secondary minimum is in February. The high temperatures and smaller amounts of precipitation have caused the smaller values of the HTQ. Its annual value is just 1.12 , which makes these regions insufficiently moist. In July and August, the HTQ value is just 0.6 to 0.8 , so that these months are seen as extremely dry.

\subsection{Region of continental climatic features}

North and east from the region of altered Mediterranean climate, there are territories of moderately continental climate. These regions comprise three thirds of the entire Kosovo territory, i.e. for the remaining Kosovo parts, they involve 1000 $m$ above sea level of the absolute height.

II-a North Metohija (Peć-Istok) Sub-region. It spreads itself between the West Metohija and Orahovac sub-regions to the south, and to the mountain wall of the North East Prokletije to the north. Therefore, it comprises the middle flow of the River Pećka Bistrica and Klina, the upper flow of the 
River Beli Drim and Metohija Podgor. The average annual temperatures verge $11^{\circ} \mathrm{C}$ Peć $\left(11.1^{\circ} \mathrm{C}\right)$, and it is only the field of Klina that has a slightly lower temperature $-10.7^{\circ} \mathrm{C}$. The average January temperature is between $-0.02^{\circ} \mathrm{C}$ in Istok and $-0.07^{\circ} \mathrm{C}$ in Klina, while the average July temperatures very between 20 and $21^{\circ} \mathrm{C}$. In thermic sense, Metohija Podgor is slightly warmer than the bottom of the Metohija Plateau. Podgor`s shelter from northern winds and the local geographic position of Klina affect this assessment a great deal. On an annual basis, there falls $750 \mathrm{~mm}$ of precipitation, slightly more falls in Peć $(871 \mathrm{~mm})$ and even less falls in Istok, $659 \mathrm{~mm}$. The maximum precipitation is in November, December and January, with the specifically differentiated secondary maximum in May. The minimum precipitation is during the two summer months, July and August. According to the monthly HTQ values, these months are seen as dry or very dry. The Drought index is 31.5 in Istok and 41.5 in Peć. Snow is a regular winter phenomenon but the snow cover hardly ever preserves, only 16.4 days in Istok, i.e. 22.5 days in Klina. The Field of Klina features an increased number of foggy days (48.4 days) especially during autumn.

II-b North Kosovo (Ibar) Sub-region. It covers the territory of northern Kosovo, i.e. parts of Ibarski Kolašin, the suburbs of Kosovska Mitrovica and the valley of the Ibar middle flow to the place of Lešak. To the south, it spreads itself to Vučitrn and it also involves northern Drenica, the high plateau of Ljušta. The average annual temperature is $10.2^{\circ} \mathrm{C}$, the minimum one is in January $-0.8^{\circ} \mathrm{C}$, as the maximum temperature is in July $20^{\circ} \mathrm{C}$. In thermic sense, this subregion represents the transition from warmer Metohija and colder Kosovo. The vegetation period is 247 days long with the temperature sum of $3543^{\circ} \mathrm{C}$. These parts of Kosovo receive extremely small amounts of precipitation (Kosovska Mitrovica 614mm, Lešak 625 $\mathrm{mm})$. In pluviometric sense, there is a strong continental effect. The maximum precipitation value is in May or June with the differentiated secondary maximum in November. The minimum precipitation value is in November and in March with the secondary minimum in August. The fact that the annual HTQ is only 1.03 is indicative of the dryness of this subregion. From May to September these parts are viewed as insufficiently moist, being viewed as extremely dry during the hottest months. The general feature of this sub-region is exquisite dryness in the warmer part of the year, moderate climates with no extremes, dry winters with little snow and rare snow cover.

II-c Malo Kosovo Climatic Sub-region. Malo Kosovo is a small sideway valley at the eastern slope of the Kosovo valley. Surrounded by mountains, it has somewhat different features when compared with the remaining part of Kosovo. The surrounding mountains play a crucial role in terms of regional climate especially the mountain of Kopaonik. The average annual temperature is lower than $10^{\circ} \mathrm{C}$. The average winter temperature is negative and even summers are colder than what seems to be the case in other climatic sub-regions. The vegetation period is 241 days long with the entire temperature sum of $3450^{\circ} \mathrm{C}$. On an annual basis, Malo Kosovo approximately receives $700 \mathrm{~mm}$ of downfall. The November and May maximums are approximately of the same values with the minimum values in August, March and February. There are not many snowy days (about 30) but the snow cover and low winter temperatures last long (43.5 days in Podujevo and 54.7 days in Kisela Banja). This part of Kosovo and Metohija also features a great level of windiness.

II-d Kosovo-Drenica Climatic Sub-region. In terms of the area it occupies, this the largest climatic subregion in Kosovo and Metohija. It involves the central part of the Kosovo Valley, from Vučitrn in the north and Lipljan in the south. It also occupies the territory in Drenica, from Srbica to Glogovac and it also comprises the eastern parts of the Metohija Valley. The low mountains between the Drenica Valley Kosovo Polje also belong to it. The average annual temperature is lower than $10^{\circ} \mathrm{C}$ but the average winter temperature is positive $\left(0.3^{\circ} \mathrm{C}\right)$. The summers are fresh because the average July temperature is just $19.8^{\circ} \mathrm{C}$. The main feature of winter is also shown by a great number of frosty days, some 100 of these, and icy days with more than 20 . The vegetation period is 245 days long with the temperature sum of $3512^{\circ} \mathrm{C}$. Central Kosovo and Eastern Metohija are the driest regions in Kosovo and Metohija. They only receive $600 \mathrm{~mm}$ of precipitation. The precipitation regime is the closest to the continental type. The maximum precipitation is in May or June as the secondary maximum is in November, being hardly visible. The precipitation maximum is near the end of winter -in February or in March, with the secondary one being practically nonexistent as the dry period stretches through the entire summer. The main feature of this region is a high level of dryness. Long dry periods are common with the 
longest one lasting for 58 days. The average annual HTQ value is only 1.06 (insufficiently moist) as in July and in August the HTQ values gets as low as 0.08 , which makes them dry. The region is also featured by considerable windiness, especially in the Lipljan area.

II-e South Kosovo Climatic Sub-region. It stretches itself in the southern part of the Kosovo Valley, from the divergence of the rivers Sitnica and Nerodmika in the north to the Kačanik Gorge in the south. The average annual temperature is $9.8^{\circ} \mathrm{C}$ but the average winter temperature is positive. The warmest month is July with $19.8^{\circ} \mathrm{C}$. The vegetation period is 244 days long with the temperature sum of $3505^{\circ} \mathrm{C}$. The South Kosovo climatic sub-region is featured by an increased amount of precipitation - Uroševac with almost $700 \mathrm{~mm}$, Štimlje near $800 \mathrm{~mm}$ and Kačanik with $860 \mathrm{~mm}$. In the pluviometric regime, the spring maximum in May is differentiated and the summer minimum is in August. Dry periods are common with the longest one lasting for 56 days. The average annual HTQ value is 1.26 which makes it an insufficiently dry area. The sub-region is also featured by great windiness. There is only $104 \% \mathrm{o}$ of silence in Uroševac.

II-f Gnjilane Climatic Sub-Region. This is also a sideway valley at the eastern edges of the Kosovo Valley. It is separated from it by low divergence so that Kosovo Valley climatic influences are dominant. To the north, it is sheltered by the Novo Brdo Mountain Area, as to the south, it sheltered by Skopska Crna Gora. This has affected the great continental feature of this sub-region. The average annual temperature is higher than $10^{\circ} \mathrm{C}$. The coldest month is January with $-0.9^{\circ} \mathrm{C}$ and the warmest moth is July with $20.7^{\circ} \mathrm{C}$. This is, to a certain extent, a subregion warmer than those nearby, so that the vegetation period is 250 days long with the temperature sum of $3680^{\circ} \mathrm{C}$. The Gnjilane Valley and the Kriva Reka Basin are one of the driest areas in Serbia. The annual amount of precipitation is smaller than $600 \mathrm{~mm}$. The greatest amount of precipitation is in May and the smallest one is in March. Long droughts are one of the features of this climatic region. The longest dry period in Kosovska Kamenica lasted for 52 days, and, in Dunav in Skopska Crna Gora, it lasted for 61 days. On average, snow appears over a 20 or 30-day period, and the snow cover lasts for 30 days in the lower parts, or more than 40 days at the edges. There is the greatest frequency of silence in Kosovo and Metohija.

\subsection{Region of mountain climatic features}

III-a Mountain Climatic Region. Besides the climatic regions of valleys and fields, climatic regions with mountainous and sub-mountainous climate can be selected in Kosovo and Metohija. Apart from Dragaš, there are no meteorological stations in these, so their basic climatic indicator have been obtained indirectly through gradients. All the edges of mountains and valleys between 1000 and 1500 metres of height have sub-mountainous climate. Above the sub- mountainous climatic belt, there is a zone of original mountainous climate. It is limited to the smaller areas of Šar Planina, Ošljak and the Prokletije Mountain. III- $a$ Prokletije Sub-region. It occupies the territory from the Junika mountains in the south, across Đeravica, Koprivnik, the mountain of Mokra, Hajla, Žljeb, Rusolija to Mokra Gora, in the north-east. The average negative monthly temperature only occurs at heights above $2200 \mathrm{~m}$ as the average negative monthly temperatures are from November to April, i.e. six months. The amount of precipitation decreases from the south-north direction. The largest amount of precipitation is received in the south-west parts of the Prokletije Mountains, at approximately $2300 \mathrm{~m}$, in the spring region of the River Pećka Bistrica 2200mm, while the north-east parts of the Prokletije Mountains receive considerably less $1200 \mathrm{~mm}$ (Ivanovic, 1991). The greatest amount of precipitation occurs in November and in December as the smallest one occurs in August. The relative disruption of precipitation decreases from the south (more than 7) to the north (Čečevo 5.26).

III-b Šar Planina Sub-region. It involves the northern slopes of Šar Planina Mountain from the Kačanicka Gorge in the east to Koritnik in the west. Apart from Šar Planina, Ošljak, Jezerska and Žar Mountain belong to this region. Two dells are embedded between these mountains, Sirinic and Sredska with more moderate climate than the nearby regions so these can be differentiated as vineyards. The average annual temperature in Dragaš $(1060 \mathrm{~m})$ is $8.3^{\circ} \mathrm{C}$ as the negative monthly temperatures are four to five months over the year. Šar Planina Mountain receives more than $800 \mathrm{~mm}$ of precipitation with the astern parts receiving slightly more than the western parts (Jažince $1011 \mathrm{~mm}$, Dragaš $813 \mathrm{~mm}$ ). The central parts of Šar Planina Mountain (Zaplužje) have 49, the 
eastern parts 42 and the western ones 34 snowy days. The snow cover lasts for 62.4 days in Dragaš, up to 95 days in Zaplužje. Wind is common. The participation of silence is just $197 \%$. The south wind also known as Jugo or Solunac has characteristics of the foehn wind.

III-c Kopaonik Sub-region. The southern and western slopes of Kopaonik belong to Kosovo and Metohija. Apart from Kopaonik, the mountain of Rogozna also belongs to this sub-region. The average annual temperature is $3.7^{\circ} \mathrm{C}$ (The meteorological observatory of Kopaonik is at the northern slopes at $1760 \mathrm{~m}$ above sea level). The coldest month is January with $-5.2^{\circ} \mathrm{C}$ as the warmest month is August with $12.8^{\circ} \mathrm{C}$. The average negative monthly temperatures occur over 4 to five months. Kopaonik receives a very small amount of precipitation. The precipitation station of Borčane (1100 m above sea level) only receives $728 \mathrm{~mm}$ of precipitation. The biggest number of precipitation is in May as the smallest one is in February and March. There are about 43 snowy days and the snow cover lasts for 76 days on average. There is noticeable windiness-the participation of silence is $174 \%$.

III-d East Kosovo Sub-region. It is located in the easternmost part of the province, between Malo Kosovo in the north and the Krivorečki Basin and the Gnjilane Valley in the south. It is composed of low mountains, $1200 \mathrm{~m}$ high, among which Koznica, Prugovac and Žegavac domineer. The average annual temperature is from 8 to $10^{\circ} \mathrm{C}$ and negative temperatures occur over two to three months. The annual amount of precipitation is approximately 800 $\mathrm{mm}$. There are approximately 30 snowy days and the snow cover lasts for about 50 days.

\section{RESULTS AND DISCUSSION}

Kosovo and Metohija have specific climate. The influences of the Mediterranean and the Eurasian continent intermingle in this territory. Thereby, it is at the transitional stage from real Mediterranean climate to real continental climate. Mediterranean influences are the strongest in southern Metohija and we move to the north and east of the province, they become weaker, so that at the easternmost frontiers, there is a visible continental feature of the climate. This has, of course, influenced the possibility of climate differentiation in Kosovo and Metohija, with the exact number of climatic regions. The high mountains surrounding the territory have influenced the selection of mountainous climatic regions with a number of subregions In Kosovo and Metohija and that with geospatial analysis in GIS software derived specially map (Valjarević et al., 2015), (Fig. 1) one may select:

- The altered Mediterranean region with three sub-regions,

- The moderately continental climatic region with three sub-regions.

- The mountainous climatic region with three sub-regions.

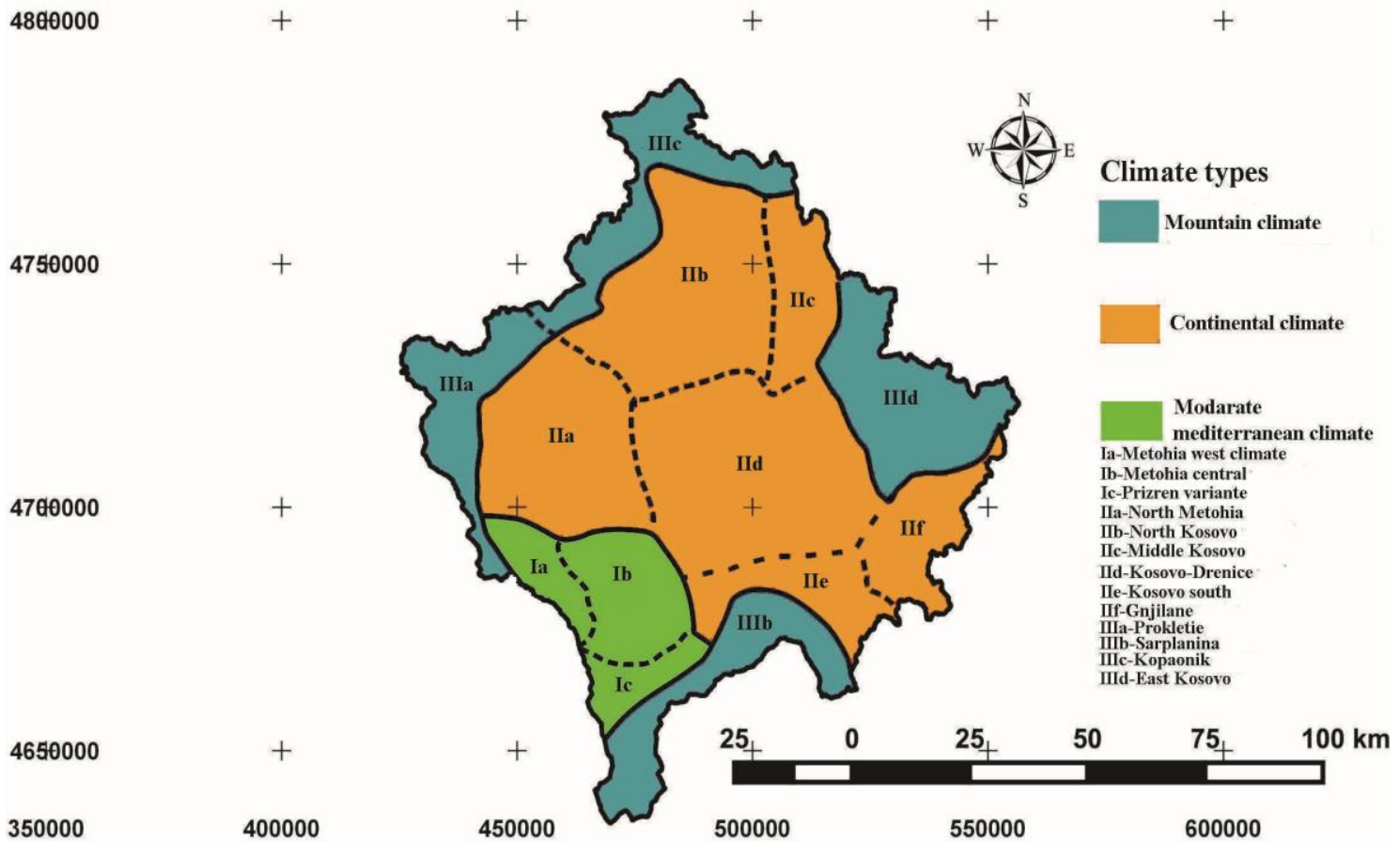

Fig. 1. Climatic Regions in Kosovo and Metohija.

\section{Geography}




\section{ACKNOWLEDGEMENT}

This work was financially supported by the Serbian Ministry of Education and Science, project No.III4008.

\section{REFERENCES}

Ivanović, R. 1991. Količina i režim padavina na Prokletijama. . In: 13. Kongres geografa Jugoslavije. Priština.

Ivanović, R. 1996. Stepen kontinentalnosti klime Kosova i Metohije. In Zbornik radova „Fizičko geografski procesi na Kosovu i Metohiji“" I. PMF Priština.

Labus, D. 1981. Klimatski rejoni Kosova i Metohije. In Geografska istraživanja 3.Priština: Geografsko društvo Kosova i Metohije.

*E-mail: radomir.ivanovic@pr.ac.rs
Otorepec, S. 1973. Prilog agroklimatskom rejoniranju uslova vlaženja u Jugoslaviji po HTK Seljaninova. Arhiv za poljoprivredne nauke, Beograd, 26(96).

Radovanović, M. 1996. Klimatska regionalizacija Metohije. GI "Jovan Cvijić" SANU, Beograd, 48. Posebna izdanja.

Rakićević, T. 1980. Klimatsko rejoniranje Srbije. Zbornik radova PMF Beograd, 27.

Valjarević, A., Srećković-Batoćanin, D., Živković, D., \& Perić, M. 2015. GIS analysis of dissipation time of landscape in the Devil's city (Serbia). Acta Montanistica Slovaca, 20(2), pp. 148-155.

Vujević, P. 1955. Razlika u visini letnjih i jesenjih padavina kao merilo njihovog maritimiteta odnosno, kontinentaliteta. Zbornik radova GI "Jovan Cvijić" SANU, . knj. 10.

Vujević, P. 1956. Klimatološka statistika.Beograd: Naučna knjiga.

\section{Geography}

